\title{
Formulation and Evaluation of Zidovudine Transdermal Patch using Permeation Enhancers
}

\author{
Jajala Mamatha, Sravya Gadili, Kanagala Pallavi* \\ Department of Pharmaceutics, G. Pulla Reddy College of Pharmacy, Hyderabad, Telangana, INDIA.
}

\begin{abstract}
Objective: The objective of this research was to study the permeation of zidovudine using permeation enhancers. Methodology: Transdermal patches were formulated using permeation enhancer namely T-Anethole. Zidovudine patches were prepared by solvent casting method. Results: The prepared patches were evaluated for drug content, thickness and weight variation folding endurance, moisture uptake, water vapor transmission, ex-vivo permeation study and skin irritation study. Fourier Transform Infrared revealed no interaction among the drug, polymers and terpene used in the present study. Different formulations were prepared and variations in drug release profiles were observed. About $67.42 \%$ of drug release was observed for TPS control patch (without permeation enhancer) whereas for TPS4 patch containing t-anethole as permeation enhancer, drug release at the end of $8 \mathrm{~h}$ was found to be $93.21 \%$. The ex vivo permeation studies were performed in 7.4 phosphate buffer saline using a Franz diffusion cell. The skin irritation test was performed on rabbits and these results
\end{abstract}

suggested that both placebo and drug-loaded films produced negligible erythema. Ex vivo studies indicated that formulation TPS4 shown better release of zidovudine for $8 \mathrm{hrs}$ with flux $614.05 \mu \mathrm{g} / \mathrm{cm}^{2} / \mathrm{hr}$. Conclusion: The transdermal patches of zidovudine using permeation enhancers done successfully.

Key words: Zidovudine, Permeation, Anethole, Permeation enhancer, Flux.

Correspondence

Mrs Pallavi Kanagala,

Department of Pharmaceutics, G. Pulla Reddy College of Pharmacy,

Hyderabad-500028, Telangana, INDIA.

Phone: +91 040-23517222

Email: pallavikanagala@gmail.com

DOI: 10.5530/jyp.2020.12s.45

\section{INTRODUCTION}

Zidovudine (Retrovir), a nucleoside reverse transcriptase inhibitor, is indicated in combination with other antiretroviral agents for the treatment of HIV-1 infection. The apparent volume of distribution of zidovudine, following oral administration, is $1.6 \pm 0.6 \mathrm{~L} / \mathrm{kg}$; and binding to plasma protein is low, $<38 \%$. After oral administration, it is rapidly absorbed from the gastrointestinal tract with a peak serum concentration occurring in about $1 \mathrm{~h}$. However, oral bioavailability of AZT is not very high, with a range of $52 \%$ to $75 \%$, due to the first-pass metabolism and the mean half-life is approximately $1 \mathrm{hr}$.

In order to maintain therapeutic levels, large doses should be given frequently in oral route. ${ }^{1}$ This dosage often causes toxic levels in blood and severe adverse effects such as granulocytopenia or anemia occurs. The side effects of AZT are usually associated with excessive plasma level of AZT immediately after intravenous or oral administration. Therefore, when compared to a delivery from oral pathway, delivery from the transdermal route may be helpful in maintaining suitable plasma concentration and in improving bioavailability and patient compliance and avoiding side effects. Zidovudine (AZT) is a polar molecule, diffusion of AZT across highly lipophilic stratum corneum is poor and below the level to achieve effective therapeutic plasma concentration. Hence, using terpenes (anethole) along with polyol such as propylene glycol and polyethylene glycol as penetration enhancers could be an effective in achieving therapeutic plasma levels for AZT. ${ }^{2-4}$

\section{MATERIALS AND METHODS}

\section{Materials}

Zidovudine was obtained from Aurobindo pharmaceuticals. Terpene was obtained from Alfa aesar Johnson Matthey Chemicals India Pvt. Ltd.
PVA was obtained from NP Chemicals, PVP was obtained from Yarro Chemicals, Propylene glycol was obtained from Otto,. Eudragit RL 100 was purchased from Evonik industries, HPMC was brought from Burgoynr Burbidges \% Co. All other chemicals were of analytical grade.

\section{Methods}

Preparation of transdermal patches

Dose calculations of drug ${ }^{5-7}$

Transdermal dose $=$ oral dose ${ }^{\star}$ bioavailability

Transdermal dose $=40^{\star} 65 / 100=26 \mathrm{mg}$

Diameter of Teflon plate: $6 \mathrm{~cm}$

Area of petri plate $=28.26 \mathrm{sq} . \mathrm{cm}$

No. of $2.3^{\star} 2.3 \mathrm{~cm}$ area films in a petri plate $=28.6 / 5.3=5.33$

Each film contains $26 \mathrm{mg}$ drug, drug to be taken per petri plate $=$ $5.33^{\star} 26=138.58 \mathrm{mg}$ (139 including practical loss).

\section{Preparation of patches ${ }^{8,9}$}

All the ingredients were weighed accurately and dissolved in a suitable solvent with continuous stirring. Then plasticizer was added to the above solution. The resultant solution was stirred for $15 \mathrm{~min}$ to get a clear solution and was kept aside for some time to get a bubble free solution, these solutions were casted slowly on a Teflon plate with a continuous flow to avoid bubble formation and the plates were kept at room temperature for $24 \mathrm{hrs}$. An inverted funnel was placed over the plate to control the rate of drying. (Table1)

After $24 \mathrm{hr}$, formed patch was taken out and checked for its complete dryness. The dried patch was gently separated from the Teflon plate and 


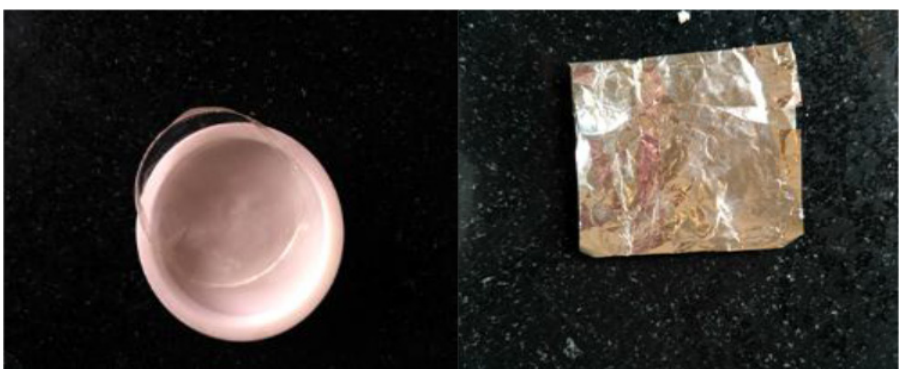

Figure 1: Prepared transdermal patch of Zidovudine.

cut into separate patches $2.3 \mathrm{~cm}^{\star} 2.3 \mathrm{~cm}$ area. (Figure 1) The patches were preserved by wrapping in aluminum foil. These patches were used for evaluation tests further.

\section{Preparation of Azt Loaded Transdermal Patches using Combination of Synthetic Polymers \\ Physicochemical Evaluation of Transdermal Patches}

Patches were evaluated for their visual inspection, film formation, weight variation, folding endurance, content uniformity, assay, thickness, drug content, in-vitro studies, ex-vivo studies, skin irritation studies and stability studies. ${ }^{10-16}$ Results were given in Table 5 and 6

\section{(A) Visual inspection and film formation}

The patch was evaluated visually for its clarity, transparency and stickiness. If it was satisfactory, then it was taken for further evaluation. If the patches were not satisfactory, then they were discarded.

\section{(B) Assay}

The assay was performed to ensure the drug loading in each patch. The assay was performed by taking out a $5.29 \mathrm{~cm}^{2}\left(2.3 \mathrm{~cm}^{\star} 2.3 \mathrm{~cm}\right)$ area of patch from the whole patch. It is dissolved in $100 \mathrm{ml}$ of phosphate buffer saline $\mathrm{pH} 7.4$ with the aid of stirring. The volumetric flask was kept on a magnetic stirrer for $6 \mathrm{hr}$ and sonicated for $15 \mathrm{mins}$ for mixing. The solution was filtered through the Whatman filter paper, diluted appropriately and the drug content was measured spectrophotometrically against corresponding placebo patches at a wavelength of $267.6 \mathrm{~nm}$.

\section{(C) Thickness variation test}

The thickness of the patches was measured at three different points using a micrometer screw gauge and mean values were calculated.

\section{(D) Weight variation test}

This test ensures the uniformity of the formed patch. From the whole patch three small pieces were cut randomly, each of $4 \mathrm{~cm}^{2}\left(2^{\star} 2 \mathrm{~cm}\right)$ area and were weighed individually. The standard deviation from the mean value was reported.

\section{(E) Folding endurance}

Folding endurance of patches was determined by repeatedly folding a small strip of patch till it broke; the number of times, the patch could be folded at the same place without breaking gave the value of folding endurance.

\section{(F) Moisture content}

The prepared films weighed individually and kept in a dessicators containing calcium chloride at room temperature for $24 \mathrm{hr}$. The films are weighed again after a specified interval until they show a constant weight. The percent moisture content was calculated by following formula.

$\%$ Moisture content $=[$ Inital weight - Final weight $/$ Final weight $] \times 100$

\section{(G) Moisture uptake}

Weighed films were kept in desicators at room temperature for $24 \mathrm{hr}$. These were taken out and exposed to $84 \%$ relative humidity using saturated solution of potassium chloride in a desicators until a constant weight is achieved.

$\%$ Moisture uptake $=[$ Final weight - Initial weight $/$ Initial weight $] \times 100$

\section{(H) Water Vapor Transmission Rate (WVTR) studies}

Glass vials of equal diameter were used as transmission cells. The transmission cells were washed thoroughly and dried in oven at $100^{\circ} \mathrm{C}$ for some time. About $1 \mathrm{~g}$ anhydrous calcium chloride was placed in the cells and respective polymer film $(1 \mathrm{sqcm})$ was fixed over the brim. The cells were accurately weighed and kept in a closed desicator containing saturated solution of potassium chloride $(200 \mathrm{ml})$ to maintain a relative humidity of $84 \%$. The cells were taken out after $24 \mathrm{~h}$ and weighed after storage. The amount of water vapor transmitted was found using the following formula.

\section{$\mathrm{WVT}=\mathrm{WL} / \mathrm{S}$}

Where,

$\mathrm{W}=$ water vapor transmitted in gm,

$\mathrm{L}=$ thickness of the film in $\mathrm{cm}$,

$\mathrm{S}=$ exposed surface area in square $\mathrm{cm}$.

Table 1: Formulation of Zidovudine patch using different synthetic polymers with t-anethole as permeation enhancer.

\begin{tabular}{|c|c|c|c|c|c|c|c|c|c|}
\hline Ingredients & TPS1 & TPS2 & TPS3 & TPS4 & TPS5 & TPS6 & TPS7 & TPS8 & TPS9 \\
\hline Zidovudine & 138 & 138 & 138 & 138 & 138 & 138 & 138 & 138 & 138 \\
\hline PVA (mg) & 100 & 200 & 300 & - & - & - & 100 & 100 & 100 \\
\hline PVP K30 (mg) & 400 & 300 & 200 & - & - & - & - & - & - \\
\hline Eudragit RL 100 (mg) & - & - & - & 400 & 300 & 200 & - & - & - \\
\hline HPMC E 15LV(mg) & - & - & - & 100 & 200 & 300 & - & - & - \\
\hline $\mathrm{Na} \mathrm{CMC}(\mathrm{mg})$ & - & - & - & - & - & - & 100 & 200 & 300 \\
\hline T-Anethole & 0.2 & 0.2 & 0.2 & 0.2 & 0.2 & 0.2 & 0.2 & 0.2 & 0.2 \\
\hline Solvent $(10 \mathrm{ml})$ & water & Water & water & $\mathrm{Dcm}: \mathrm{Et}$ & Dcm:Et & $\mathrm{Dcm}: \mathrm{Et}$ & water & water & water \\
\hline Plasticizer & glycerol & glycerol & glycerol & PG & PG & PG & PG & PG & PG \\
\hline
\end{tabular}

NOTE: All the ingredients are dissolved in $10 \mathrm{ml}$ of solvent

Dcm:Et-Dichloromethane:ethanol in 1:1 ratio 
It is expressed as the number of grams of moisture gained $/ \mathrm{h} / \mathrm{cm}^{2}$.

\section{Ex-vivo Permeation Studies}

\section{Preparation of goat skin for ex-vivo studies}

Fresh abdominal skin of the goat was collected from the slaughter house. Abdominal skin hair was removed using an animal hair clipper, a portion of skin was separated andadipose tissue was surgically removed and dermis side was wiped with isopropyl alcohol to remove residual adhering fat.The skin was washed with phosphate saline buffer (PBS) pH 7.4 and was stored at $-20^{\circ} \mathrm{C}$ and used within four days. ${ }^{17-19}$

\section{Ex-vivo Permeation studies using goat skin}

For the permeation studies locally fabricated Franz diffusion cells with $25 \mathrm{ml}$ receptor volume were used. The thawed rat skin was mounted onto diffusion cell such that the dermis side was in constant contact with receptor solution. Patch was applied to the stratum corneum facing the donor compartment and the receptor fluid was agitated at $100 \mathrm{rpm}$ by magnetic stirrer and the temperature was maintained at $32 \pm 0.5^{\circ} \mathrm{C} .1 \mathrm{ml}$ sample was withdrawn at predetermined time intervals for $8 \mathrm{hrs}$ and drug content was analyzed by UV-VIS double beam spectrophotometer at $267.6 \mathrm{~nm} \cdot{ }^{20,21}$

\section{Calculation of permeability parameters}

\section{(A) Steady state flux $\left(\mu \mathrm{g} / \mathrm{cm}^{2} / \mathrm{hr}\right)$}

Steady state flux (Jss) is defined as the rate of diffusion or transport of a substance through a permeable membrane. After reaching the steady state of drug permeation, the flux was calculated using the following equation.

$$
\text { Jss }=\frac{\mathrm{dM}}{\mathrm{s}} \mathrm{dt}
$$

dM-amount of drug permeated

S-unit cross-section area

$\mathrm{t}$-time $(\mathrm{t})$.

The steady state flux obtained by plotting the cumulative amount of drug permeated in micrograms per square centimeter versus time in hours and the slope is the flux. Lag time is $\mathrm{X}$ intercept of this graph. ${ }^{22,24}$

\section{(B) Permeability coefficient $(\mathrm{cm} / \mathrm{hr})$}

The permeability coefficient $(\mathrm{Kp})$ was calculated with the following equation:

$$
\mathrm{Kp}=\frac{\mathrm{Jss}}{\mathrm{cv}}
$$

Where, $\mathrm{cv}$ is the total donor concentration of the formulation ${ }^{25}$

\section{(C) Enhancement ratio}

Enhancement ratio (ER) used to evaluate the effect of permeation enhancer on the diffusion and permeation of selected drug molecules and is calculated by

$$
\mathrm{ER}=\frac{\text { Jss of drug with enhancer }}{\text { Jss of drug alone }}
$$

Where, Jss - Steady state flux ${ }^{26}$

\section{(D) Lag time (min)}

Lag time is the time required for the drug to get released from the reservoir. It is calculated by plotting the cumulative amount of drug permeated v/s time. The $\mathrm{x}$-intercept value gives the lag time.

\section{Calculation of model dependent kinetics for prepared patch formulations}

Various models were tested for explaining the kinetics of drug release. To analyze the mechanism of the drug release rate kinetics of the dosage form, the obtained data were fitted into zero-order, first order, Higuchi and Korsmeyer-peppas release model, to study the drug release from the dosage form. ${ }^{27-29}$

\section{Drug kinetics}

In order to understand the mechanism and kinetics of drug release from the drug reservoir through rate controlling membrane, the in-vitro data was related with the following mathematical models as shown in Table 2 and 3.

\section{Skin Irritation Studies}

Skin irritation studies were performed on rabbits after the approval by the Institutional animal Ethical Committee (IAEC) in G. Pulla Reddy College of Pharmacy, Registration number 320/CPCSEA and ID no: GPRCP/IAEC/10/18/02/PCE/AE-4.

A primary skin irritation test was performed.Since, skin is the vital organ through which the drug is transported. The test was carried out on two healthy rabbits weighing between $1.5-2 \mathrm{~kg}$. The test was conducted on an unbraided skin of rabbits. The unbraided skin was cleaned with rectified spirit for placing the patches. The control patch was placed on the left dorsal surface of each rabbit, whereas the test patch with the drug was placed on the right dorsal surface of the same rabbit and the other rabbit was kept as control. The patches were removed after $24 \mathrm{hrs}$ and the skin was examined for erythema/ oedema. ${ }^{30,31}$

Table 2: Model dependent kinetics. ${ }^{32-34}$

\begin{tabular}{cccc}
\hline Model & Equation & Plot of graph & Parameters \\
\hline Zero order & $\mathrm{Q}_{\mathrm{t}}=\mathrm{Q}_{0}+\mathrm{K}_{\mathrm{o}} \mathrm{t}$ & $\begin{array}{c}\text { \% drug release } \\
\text { versus time }\end{array}$ & $\begin{array}{c}\mathrm{K}_{\mathrm{o}} \text { - release rate } \\
\text { constant }\end{array}$ \\
First order & $\ln \mathrm{Q}_{\mathrm{t}}=\ln \mathrm{Q}_{0}+\mathrm{K}_{\mathrm{l}} \mathrm{t}$ & $\begin{array}{c}\text { log \% drug release } \\
\text { versus time }\end{array}$ & $\begin{array}{c}\text { K1- release rate } \\
\text { constant }\end{array}$ \\
$\begin{array}{c}\text { Higuchi } \\
\text { release }\end{array}$ & $\mathrm{Q}_{\mathrm{t}}=\mathrm{K}_{\mathrm{H}} \mathrm{t}^{1 / 2}$ & $\begin{array}{c}\% \text { drug release } \\
\text { versus square root } \\
\text { of time }\end{array}$ & $\begin{array}{c}\mathrm{K}_{\mathrm{H}} \text {-Higuchi } \\
\text { constant }\end{array}$ \\
$\begin{array}{c}\text { Korsmeyer- } \\
\text { Peppas }\end{array}$ & $\mathrm{Q}_{\mathrm{t}} / \mathrm{Q}_{\infty}=\mathrm{K}_{\mathrm{k}} \mathrm{t}_{\mathrm{n}}$ & $\begin{array}{c}\text { log \% drug release } \\
\text { versus log time }\end{array}$ & $\begin{array}{c}\text { n-release } \\
\text { exponent }\end{array}$ \\
\hline
\end{tabular}

Regression coefficient $\left(\mathrm{r}^{2}\right)$ was calculated for all the formulations. Release component " $n$ " was calculated from Korsmeyer-peppas equation. These calculations were carried out using MS-office excel.

Table 3: Interpretation of diffusion release mechanism from " $n$ " values. ${ }^{35,36}$

\begin{tabular}{ccc}
\hline Release Exponent $(\mathrm{n})$ & Drug transport mechanism & $\begin{array}{c}\text { Rate as a function } \\
\text { of time }\end{array}$ \\
\hline$<0.5$ & Fickian diffusion & $\mathrm{t}^{-0.5}$ \\
$0.5<\mathrm{n}<1.0$ & Anomalous transport & $\mathrm{t}^{\mathrm{n}-1}$ \\
1.0 & Case-II transport & Zero order release \\
Higher than 1.0 & Super case-II transport & $\mathrm{t}^{\mathrm{n}-1}$ \\
\hline
\end{tabular}




\section{Stability Studies}

Stability is defined as the extent to which a product retains within the specified limits and throughout is period of storage and use i.e., shelf life. Stability studies were carried out on optimized formulation according to International Conference on Harmonization $(\mathrm{ICH})$ guidelines.

The formulation packed in aluminum foil was subjected to stability testing in aluminum foil for a month at room temperature. Samples were taken at regular time intervals of 15 days for over a period of 1 month and analyzed for the change in physical appearance and the drug content by procedure stated earlier. Tests were carried out in triplicate and mean value of the observed values was noted along with standard deviation.

Ex-vivo permeation rate studies such as \% drug release, steady state transdermal flux (SSTF), permeability coefficient, lag time and enhancement ratio of percutaneous absorption of zidovudine were calculated. ${ }^{39-41}$

\section{Evaluation Tests for Transdermal Patches Containing Synthetic Polymers}

\section{Ex-vivo Diffusion Studies of Transdermal Patch Containing Synthetic Polymers}

\section{Evaluation of Control Patch}

Control patches were prepared similar to the optimized formulation TPS4 without terpene.

Evaluation and Ex-vivo diffusion studies were performed. The results were shown in Table 8-11.

From the results of ex-vivo drug release kinetics for optimized patch formulations as shown in Table 4. It was found that formulations follow first order release kinetics.

From the values of release component " $n$ ", it can be concluded that both the formulations have anamolous diffusional release mechanism. Drug release has shown peppas release mechanism, this may be due to presence of swelling polymers in the patch. Anamolous diffusion or nonfickian diffusion refers to a combination of both diffusion and erosion controlled release. The release process involves the penetration of solvent into the patch followed by swelling of the polymer and the diffusion of the drug dissolved in the matrix.

\section{Stability Studies}

Stability studies were done for the optimized formulation TPS4. There were no insignificant physical changes in appearance and flexibility. After subjecting the optimized formulations to the accelerated stability
Table 4: Grading scale of the Draize method. ${ }^{37,38}$

\begin{tabular}{ccc} 
S.No & Grade & Formation of erythema and edema \\
\hline 1 & 0 & None \\
2 & 1 & Slight \\
3 & 2 & Well defined \\
4 & 3 & Moderate \\
5 & 4 & Severe erythema and edema \\
\hline
\end{tabular}

Table 5: Evaluation tests for transdermal patches containing synthetic polymers.

\begin{tabular}{ccccc}
$\begin{array}{c}\text { Formulation } \\
\text { code }\end{array}$ & $\begin{array}{c}\text { Weight } \\
\text { variation }\end{array}$ & $\begin{array}{c}\text { Folding } \\
\text { endurance }\end{array}$ & $\begin{array}{c}\text { Thickness } \\
(\mathbf{m m})\end{array}$ & $\begin{array}{c}\text { Drug } \\
\text { content }\end{array}$ \\
TPS1 & $133 \pm 1.7$ & 120 & $0.21 \pm 0.01$ & $97.05 \pm 2.23$ \\
TPS2 & $135 \pm 1$ & 146 & $0.22 \pm 0.01$ & $96.44 \pm 1.94$ \\
TPS3 & $134 \pm 2.08$ & 185 & $0.26 \pm 0.02$ & $95.75 \pm 3.23$ \\
TPS4 & $167 \pm 0.57$ & 158 & $0.23 \pm 0.01$ & $97.23 \pm 1.08$ \\
TPS5 & $141 \pm 0.57$ & 130 & $0.23 \pm 0.02$ & $97.60 \pm 1.87$ \\
TPS6 & $166 \pm 3.21$ & 168 & $0.25 \pm 0.01$ & $97.98 \pm 1.05$ \\
TPS7 & $76 \pm 2$ & 285 & $0.16 \pm 0.01$ & $97.27 \pm 1.90$ \\
TPS8 & $93.3 \pm 1.15$ & $>300$ & $0.17 \pm 0.01$ & $96.89 \pm 2.9$ \\
TPS9 & $138.6 \pm 1.15$ & 184 & $0.19 \pm 0.01$ & $98.11 \pm 1.35$ \\
\hline
\end{tabular}

$\mathrm{n}=3$, Results are the mean of triplicate observations \pm S.D values.

Table 6: Evaluation tests for transdermal patches containing synthetic polymers.

\begin{tabular}{cccc}
$\begin{array}{c}\text { Formulation } \\
\text { code }\end{array}$ & Moisture uptake & $\begin{array}{c}\text { Moisture } \\
\text { content }\end{array}$ & $\begin{array}{c}\text { WVTR } \\
\left(\mathbf{g m} / \mathrm{cm}^{2} / \mathbf{h r}\right)\end{array}$ \\
\hline TPS1 & $6.9 \pm 0.17$ & $2.30 \pm 0.05$ & 0.018 \\
\hline TPS2 & $7.42 \pm 0.41$ & $2.27 \pm 0.2$ & 0.032 \\
TPS3 & $6.74 \pm 0.42$ & $3.07 \pm 0.16$ & 0.03 \\
TPS4 & $2.13 \pm 0.07$ & $1.22 \pm 0.8$ & 0.017 \\
TPS5 & $2.42 \pm 0.18$ & $2.17 \pm 0.82$ & 0.028 \\
TPS6 & $3.23 \pm 0.04$ & $1.82 \pm 0.24$ & 0.019 \\
TPS7 & $3.95 \pm 0.03$ & $2.7 \pm 0.19$ & 0.024 \\
TPS8 & $2.91 \pm 0.17$ & $1.41 \pm 0.24$ & 0.022 \\
TPS9 & $3.18 \pm 0.19$ & $2.66 \pm 0.31$ & 0.028 \\
\hline
\end{tabular}

All the values are expressed as mean $\pm S D, n=3$

Table 7: Ex-vivo diffusion studies of transdermal patch containing synthetic polymers.

\begin{tabular}{ccccccccccc}
\hline Time (hrs) & TPS1 & TPS2 & TPS3 & TPS4 & TPS5 & TPS6 & TPS7 & TPS8 & TPS9 \\
\hline 1 & $12.22 \pm 0.19$ & $15.02 \pm 0.10$ & $20.63 \pm 0.4$ & $18.6 \pm 0.19$ & $19.05 \pm 0.52$ & $13.3 \pm 0.41$ & $20.45 \pm 0.42$ & $17.29 \pm 0.35$ & $18.64 \pm 0.50$ \\
2 & $19.23 \pm 0.22$ & $20.23 \pm 0.08$ & $23.35 \pm 0.34$ & $24.75 \pm 0.09$ & $29.05 \pm 0.15$ & $19.05 \pm 0.17$ & $21.18 \pm 0.53$ & $18.96 \pm 0.42$ & $24.52 \pm 0.31$ \\
3 & $25.7 \pm 0.23$ & $28.37 \pm 0.09$ & $29.19 \pm 0.26$ & $30.95 \pm 0.27$ & $36.02 \pm 0.09$ & $29.05 \pm 0.39$ & $24.52 \pm 0.26$ & $24.8 \pm 0.65$ & $27.06 \pm 0.36$ \\
4 & $38.24 \pm 0.11$ & $36.74 \pm 0.11$ & $36.74 \pm 0.25$ & $41.54 \pm 0.33$ & $38.1 \pm 0.07$ & $38.1 \pm 0.09$ & $35.16 \pm 0.19$ & $30.8 \pm 0.47$ & $39.59 \pm 0.52$ \\
5 & $43.76 \pm 0.24$ & $43.67 \pm 0.24$ & $44.71 \pm 0.15$ & $57.01 \pm 0.02$ & $41.9 \pm 0.82$ & $41.9 \pm 0.41$ & $40.36 \pm 0.18$ & $39.59 \pm 0.20$ & $41.81 \pm 0.19$ \\
6 & $65.61 \pm 0.26$ & $56.11 \pm 0.09$ & $57.01 \pm 0.28$ & $62.9 \pm 0.15$ & $62.44 \pm 0.55$ & $42.58 \pm 0.82$ & $44.16 \pm 0.36$ & $41.27 \pm 0.44$ & $54.75 \pm 0.31$ \\
7 & $76.02 \pm 0.09$ & $79.64 \pm 0.07$ & $60.63 \pm 0.14$ & $80.54 \pm 0.39$ & $71.95 \pm 0.39$ & $64.25 \pm 0.83$ & $57.01 \pm 0.54$ & $65.61 \pm 0.41$ & $76.02 \pm 0.11$ \\
8 & $83.26 \pm 0.07$ & $88.69 \pm 0.14$ & $89.59 \pm 0.26$ & $93.21 \pm 0.15$ & $81 \pm 0.33$ & $76.47 \pm 0.39$ & $89.59 \pm 0.12$ & $84.16 \pm 0.19$ & $85.52 \pm 0.12$ \\
\hline
\end{tabular}

All the values are expressed as mean $\pm S D, n=3$ 
Table 8: Physico Chemical parameters of control patches.

\begin{tabular}{cccc}
\hline $\begin{array}{c}\text { Formulation } \\
\text { code }\end{array}$ & $\begin{array}{c}\text { Weight } \\
\text { variation }(\mathbf{m g})\end{array}$ & Folding endurance & Thickness $(\mathrm{mm})$ \\
\hline TPS & $159 \pm 0.02$ & 145 & $0.22 \pm 0.01$ \\
\hline
\end{tabular}

Table 9: Ex-vivo drug release profile of control zidovudine patch formulations.

\begin{tabular}{cc|}
\hline Time & Cumulative \% drug release \\
\cline { 2 - 2 } (hrs) & TPS \\
\hline 1 & $9.72 \pm 0.51$ \\
2 & $16.33 \pm 0.96$ \\
3 & $18.77 \pm 0.48$ \\
4 & $27.01 \pm 0.89$ \\
5 & $30.67 \pm 1.03$ \\
6 & $38.37 \pm 0.65$ \\
7 & $43.75 \pm 0.56$ \\
8 & $67.42 \pm 1.51$ \\
\hline
\end{tabular}

Note: All the values are express as mean $\pm S D, n=3$

Table 10: flux of control formulation.

\begin{tabular}{cc}
\hline Formulation code & Flux $(\mu \mathrm{g} / \mathrm{cm} 2 / \mathrm{hr})$ \\
\hline TPS & 381.15 \\
\hline
\end{tabular}

Table 11: Ex-vivo drug release kinetics of optimized formulations.

\begin{tabular}{|c|c|c|c|c|c|c|}
\hline \multirow{2}{*}{$\begin{array}{l}\text { Formulation } \\
\text { code }\end{array}$} & \multicolumn{4}{|c|}{$r^{2}$} & \multirow{2}{*}{$n$} & \multirow{2}{*}{$\begin{array}{c}\text { Drug } \\
\text { transport } \\
\text { mechanism }\end{array}$} \\
\hline & Zero & First & Higuchi & Peppas & & \\
\hline TPS4 & 0.979 & 0.987 & 0.927 & 0.959 & 0.815 & $\begin{array}{c}\text { Anomalous } \\
\text { transport }\end{array}$ \\
\hline
\end{tabular}

Table 12: Stability study data.

\begin{tabular}{ccccc}
\hline Parameters & $\begin{array}{c}\text { Formulation } \\
\text { code }\end{array}$ & Initial & $\begin{array}{c}\text { After 15 } \\
\text { days }\end{array}$ & $\begin{array}{c}\text { After 1 } \\
\text { month }\end{array}$ \\
\hline $\begin{array}{c}\text { Folding } \\
\text { endurance } \\
\begin{array}{c}\text { Drug content } \\
(\%)\end{array}\end{array}$ & TPS4 & 154 & 150 & 143 \\
\hline
\end{tabular}

studies, the results shown (Table 12) that there were no major changes in drug content. Hence the formulation was found to be stable.

\section{CONCLUSION}

Zidovudine transdermal patches were successfully prepared by solvent casting method using different natural and synthetic polymers using permeation enhancers and various concentrations of the same were optimized. Drug excipient compatibility studies concluded that the drug and excipient are compatible with each other. Formulations containing 4\% Eudragit RL 100 and 1\% HPMC (TPS4) were optimized among transdermal patch formulations containing synthetic polymers.
The prepared patches were evaluated for physico-chemical parameters to justify their suitability for transdermal use. About $67.42 \%$ of drug release was observed for TPS without permeation enhancer whereas for TPS4 patche containing $\mathrm{t}$-anethole as permeation enhancer, drug release at the end of $8 \mathrm{~h}$ was found to be $93.21 \%$. This clearly shows the effect of permeation enhancer, $\mathrm{t}$-anethole along with plasticizer propylene glycol (which is also a permeation enhancer) in the formulation in enhancing drug release.

Ex vivo studies indicated that formulations TPS4 shown better release of zidovudine for $8 \mathrm{hrs}$ with flux and $614.05 \mu \mathrm{g} / \mathrm{cm} 2 / \mathrm{hr}$. Skin irritation studies were performed and it indicated that the control and optimized patches did not cause any skin irritation. The optimized patch formulations were found to be stable for one month at room temperature.

\section{Future Scope}

Further studies are recommended to prove its therapeutic utility in animals by conducting pharmacokinetic and pharmacodynamics studies.

\section{ACKNOWLEDGEMENT}

The authors are thankful to principal and management of G. Pulla Reddy College of Pharmacy, Hyderabad for providing facilities to conduct our research.

\section{CONFLICT OF INTEREST}

Authors declare that there is no conflict of interest.

\section{REFERENCES}

1. NK Jain. Advances in Controlled and Novel Drug Delivery Systems, $1^{\text {st }}$ edition, Chapter 7, New Delhi, CBS Publications. 2001;138-241

2. Chein YW. Novel Drug Delivery Systems. Marcel Dekker, New York. 1992;50:301.

3. Vyas SP, Khar. Controlled Drug Delivery. Vallabh Prakashan. 2002;412-3.

4. Ashok KJ, Nikhila P, Lakshmana PS, Gopal V. Transdermal drug delivery system: An overview. Int J Pharm Sci Rev Res. 2010;6(3):49-54.

5. Mundargi RC, Babu VR, Rangaswamy V, Aminabhavi TM. Formulation and in vitro Evaluation of Transdermal Delivery of Zidovudine: An Anti-HIV Drug. Journal of Applied Polymer Science. 2011;119(3):1268-74.

6. Shalu R, Saroha K, Syan N, Mathur P. Transdermal patches a successful tool in transdermal drug delivery system. Pelgia Res Lib. 2011;2(5):17-29.

7. Zidovudine: FDA Document Available from https://www.accessdata.fda.gov/ drugsatfda_docs/label/2008/019910s033lbl.pdf

8. Available from https://aidsinfo.nih.gov/drugs/4/zidovudine/0/patient

9. Sachan R, Bajpai M. Transdermal drug delivery system: A Review. Int J Res Dev Pharm L Sci. 2013;3(1):748-65

10. Ashvini SK, Mukesh PR, Shilpa PC. Transdermal Drug Delivery: An Overview. International Journal of Research and Development in Pharmacy and Life Sciences. 2014;3(4):1042-53. ISSN: 2278-0238

11. Audumbar DM, Ritesh B, Manojkumar P. An Updated Review on Transdermal Drug Delivery Systems. International Journal of Advances in Scientific Research. 2015;1(6):244-54

12. Darshan KR. Novel Approach: Transdermal Gel. International Journal of Pharma Research and Review. 2015;4(10):41-50

13. Rastogi $\bigvee$, Yadav P. Transdermal drug delivery system: An overview. Asian Journal of Pharmaceutics. 2012;6(3):161-70.

14. Arunachalam A, Karthikeyan M, Kumar D, Prathap M, Sethuraman $S$ Ashutoshkumar S, et al. Transdermal Drug Delivery System: A Review, Current Pharma Research. 2010;1(1):70-81.

15. Mathur V, Satrawala. Y, Rajput, MS. Physical and Chemical Penetration Enhancers in Transdermal Drug Delivery System. Asian Journal of Pharmacy. 2010;4(3):173-83

16. Iman IS, Nadia AS, Ebtsam MA. Formulation and stability study of chlorpheniramine maleate transdermal patch. Asian J Pharm. 2014;4:17-23

17. Sachan R, Bajpai M. Transdermal drug delivery system: A Review. Int J Res Dev Pharm L Sci. 2013;3(1):748-65.

18. Himanshi Tanwar, Ruchika Sachdeva. Transdermal Drug Delivery System: A Review. International journal of Pharmaceutical Sciences and Research. 2016;2274-90

19. Kararli TT, Kirchhoff CF, Penzotti SC. Enhancement of transdermal transport of 
azidothymidine (AZT) with novel terpene and terpene-like enhancers: in vivo-in vitro correlations. Journal of Controlled Release. 1995;34:43-51.

20. Narishetty ST, Panchagnula R. Transdermal delivery system for zidovudine: in vitro, ex vivo and in vivo evaluation. Biopharm Drug Dispos. 2004;25(1):9-20.

21. Saraswathi R, Krishnan PN, Dilip C, Shabir ATK. Formulation and evaluation of transdermal patches of curcumin. Scholar Research Library. 2010;2(5):117-26.

22. Rakesh PP, Patel G, Bari A. Formulation and evaluation of transdermal patch of Aceclofenac. International Journal of Drug Delivery. 2009;41-51.

23. Prabhakar DJ, Sreekanth KNJ. Transdermal drug delivery patches: a review'. Journal of Drug Delivery and Therapeutics. 2013;3(4):213-21.

24. Marimutho J, Varghese N, Jaganadan SK, Sudagar D. Formulation and Evaluation of Zidovudine Mucoadhesive Buccal Patches. International Journal of Pharmacology and Pharmaceutical Sciences. 2016;3(4):30-40.

25. Dibyalochan Mohanty, Vasudha Bakshi. Formulation and Characterization of Transdermal Patches of Amlodipine Besylate Using Olive Oil as the Natural Permeation Enhancer. Indo American Journal of Pharmaceutical Research. 2016:6(6).

26. Patel P, Bhaskar VH. Formulation and Evaluation of Reservoir Type Transderma Patches of 18- $\beta$-Glycyrrhetic Acid with Piperine as Bioenhancer. Indo American Journal of Pharm Research. 2014:4(3).

27. Lesetja L, David D. In-vitro transdermal penetration of cytarabine and its N4alkylamide derivatives. The Journal of Pharmacy and Pharmacology. 2010;62: 756-61. 10.1211/jpp.62.06.0012

28. Kriplani P, Sharma A, Aman, Dhingra A, Chopra B. Formulation and Evaluation of Transdermal Patch of Diclofenac Sodium. Global Journal of Pharmacy and Pharmaceutical Sciences 2018. ISSN: 2573-2250. DOI: 10.19080/ GJPPS.2018.04.555647

29. Mandava K, Rao K, Cherukuri S, Uma RB. Formulation and evaluation of transdermal drug delivery of topiramate. International Journal of Pharmaceutical investigation. 2017; 7(1):10-7

30. Gupta A, Gidwani B, Kaur CD, Patel DK, Sahu J. Formulation And Evaluation
Of Transdermal Patch Using Antioxidant Phytoconstituent. Journal of Biological Science. 2016;2(4).

31. Lakshmi PK, Mounika K, Saroja CH. Transdermal Permeation Enhancement of Lamotrigine Using Terpenes. J Pharma Care Health Sys. 2014;1:103. DOI: 10.4172/jpchs. 1000103

32. Shailesh T. Prajapathi, Charmi G. Patel, Chhagan N. Patel. Formulation and Evaluation of Transdermal Patch of Repaglinide. ISRN Pharmaceutics. 2011. Article ID 651909

33. Tanwar H, Sachdeva R. Transdermal Drug Delivery System: A Review. Int J Pharm Sci Res. 2016;7(6):2274-90. doi: 10.13040/IJPSR.0975-8232.7(6).2274-90

34. AD Mali. An updated review on transdermal drug delivery systems. International Journal of Advances in Scientific Research. 2015;1(6):244-54.

35. Sharma B, Yadav B, Saroha K, Nanda S. Formulation and Characterization of Transdermal Patch of Amlodipine Besylate. International Journal of Pharmaceutical And Chemical Sciences. 2012;1(3). ISSN: 2277-5005.

36. Atilay E. Studies on Transdermal Delivery Enhancement of Zidovudine. AAPS Pharm Sci Tech. 2009;10(1):88-97.

37. Kavitha K, Kumar DP. Development of transdermal patches of nicardipine hydrochloride: An attempt to improve bioavailability. Int J Biomed Pharmaceut Sci. 2011;2:285-93.

38. Sinha VR, Kaur MP. Permeation Enhancers for Transdermal Drug Delivery. Drug Dev Ind Pharm. 2000;26(11):1131-40.

39. Asija R, Gupta A, Maheshwari BS. Formulation and evaluation of Transdermal patches of Torasemide. International Journal of Advances in Scientific Research. 2015;1(1):38-44.

40. Jyotsana R. Madan, Nitin S. Argade, Kamal Dua. Formulation and Evaluation of Transdermal Patches of Donepezi. Recent Patents on Drug Delivery and Formulation. 2015:9(1)95-103.

41. Limpongsa E, Umprayn K. Preparation and Evaluation of Diltiazem Hydrochloride Diffusion-Controlled Transdermal Delivery System. AAPS Pharm Sci Tech. $2008 ; 9(2)$.

Article History: Submission Date : 09-03-2020; Revised Date : 03-05-2020; Acceptance Date : 01-06-2020.

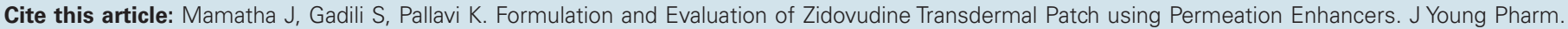
2020;12(2)Suppl:s45-s50 